\title{
First report of Entyloma gaillardianum on Gaillardia $\times$ grandiflora in Italy
}

\author{
Angelo Garibaldi ${ }^{1} \cdot$ Giovanna Gilardi $^{1}$ [D $\cdot$ Slavica Matic ${ }^{1} \cdot$ Maria Lodovica Gullino $^{1}$
}

Received: 24 September 2018 / Accepted: 12 February 2019 / Published online: 22 February 2019

(C) Società Italiana di Patologia Vegetale (S.I.Pa.V.) 2019

Keywords Ornamentals · Blanket flower · Leaf smut · Asteraceae

Starting in June 2017, six-month-old plants of blanket flower (Gaillardia $\times$ grandiflora Van Houtte) grown in a private garden located near Biella (Latitude: $45^{\circ} 36^{\prime} 00^{\prime \prime} \mathrm{N}$, Longitude: $8^{\circ} 03^{\prime} 00^{\prime \prime} \mathrm{E}$ ) in Northern Italy showed light green circular spots on leaves, from 0.7 to $1.5 \mathrm{~cm}$ in diameter, sometimes coalescent. Eventually, spots turned brown and necrotic. Microscopic examination of leaf tissue sections showed sori composed by massive double-walled hyaline to yellowish spores in the intercellular spaces of the host tissue (9.5$13.1 \mu \mathrm{m}$ in diameter), typical of the teliospores of the genus Entyloma. DNA was extracted from sori by using the E.Z.N.A. Fungal DNA Mini Kit (Omega BioTek). The internal transcribed spacer (ITS) regions of rDNA of the isolate IT63 was amplified using the primers ITS1/ITS4 (Altschul et al. 1997), and sequenced at the BMR Genomics Centre (Padua, Italy). The $674 \mathrm{bp}$ product of this isolate was deposited (Accession No. MH430594) and a BLASTn search showed a $100 \%$ similarity with Entyloma gaillardianum Vánky (AY081037). Pathogenicity was confirmed by spraying a spore suspension $\left(1 \times 10^{5} \mathrm{ml}^{-1}\right)$, prepared from homogenized infected leaves, on three potted plants of G. $\times$ grandiflora, while the same number of control plants were sprayed with sterile water. Plants were kept in green- house $\left(22-24{ }^{\circ} \mathrm{C}\right.$ at $100 \%$ of relative humidity for 5 days). All inoculated plants developed typical spots after 15 days, while no symptoms developed on the control plants. This is the first report of E. gaillardianum on Gaillardia $\times$ grandiflora in Italy, while it was previously reported in California (Farr and Rossman 2018). Garibaldi et al. (2018) reported a leaf smut caused by E. gaillardianum on $G$. aristata Pursh in Italy.

Publisher's note Springer Nature remains neutral with regard to jurisdictional claims in published maps and institutional affiliations.

\section{References}

Altschul SF, Madden TL, Schaffer AA, Zhang Z, Miller W, Lipman DJ (1997) Gapped BLAST and PSI-BLAST: a new generation of protein database search programme. Nucleic Acids Res 25:3389-3402

Farr DF, Rossman AY (2018). Fungal databases. Syst. Mycol. Microbiol. Lab., Online publication, ARS, USDA. Retrieved from http://nt.arsgrin.gov/fungaldatabases/. Accessed 3 June 2018

Garibaldi A, Gilardi G, Matic S, Gullino ML (2018) First report of leaf smut caused by Entyloma gaillardianum on Gaillardia aristata in Italy. Plant Dis 102:678
Angelo Garibaldi

giovanna.gilardi@unito.it

1 Centre of Competence for the Innovation in the Agro-Environmental Sector (AGROINNOVA), University of Torino, Largo P. Braccini 2, 10095 Grugliasco, Italy 